\begin{tabular}{l|l|l} 
Jurnal Eksplorasi Akuntansi & $\begin{array}{l}\text { ISSN : 2656-3649 (Online) } \\
\text { holt 1, No 3, Seri A, Agustus 2019, Hal 922-941 }\end{array}$
\end{tabular}

\title{
ANALISIS PENGUNGKAPAN CORPORATE SOCIAL RESPONSIBILITY PT. ANEKA TAMBANG TbK BERDASARKAN GLOBAL REPORTING INITIATIVES (GRI) DAN KAITANNYA TERHADAP PROPER
}

\author{
Nurul Addini' ${ }^{1}$, Charoline Cheisviyanny ${ }^{2}$, Mia Angelina Setiawan ${ }^{3}$ \\ 1) Alumni Jurusan Akuntansi Fakultas Ekonomi Universitas Negeri Padang \\ 2,3) Jurusan Akuntansi Fakultas Ekonomi Universitas Negeri Padang \\ *Korespondensi: muftiaddini@gmail.com
}

\begin{abstract}
This study aims to analyze: 1) The level of Corporate Social Responsibility (CSR) disclosure of PT Aneka Tambang, Tbk for the year 2017 and 2018 based on the GRI G4 Guideliness, 2) The similarity of each indicator contained in GRI G4 with PROPER which are issued by the Indonesian Ministry of Environment. This is a descriptive qualitative research using Sustainability Report of PT Aneka Tambang, Tbk for the year 2017-2018. Data for this study were secondary data were analysed using content analysis technique. The results show that: 1) Based on the result of content analysis on the level of disclousure of economic, social and environmental performance indicators on Corporate Social Responsibility disclousure of PT ANTAM is higher for 2017 compared to those of 2018. The breadth and depth ofCorporate Social Responsibility disclosure of PT ANTAM in 2017, is better compared to those of 2018. 2) In GRI G.4 especially enviromental aspects, there are several indicator items that have similarities with PROPER valuation indicator.
\end{abstract}

Keywords: Corporate Social Responsibility Disclosur; Global Reporting Initiaitives G.4; PROPER

\section{How to cite (APA $6^{\text {th }}$ style)}

Addini, N., Cheisviyanny, C., \& Setiawan, M.A. (2019). Analisis Pengungkapan Corporate Social Responsibility Perusahaan Aneka Tambang Tbk Berdasarkan Global Reporting Initiatives (GRI) dan Kaitannya terhadap PROPER. Jurnal Eksplorasi Akuntansi, 1(3), Seri A, 922-941.

\section{PENDAHULUAN}

Indonesia merupakan salah satu negara kesatuan yang secara geografisnya terdiri dari banyak pulau. Sebagai negara kepulauan terluas di dunia Indonesia memilikibanyak kekayaan berupa sumber daya alam mulai dari potensi laut, hutan, dan tambang. Potensi sumber daya tambang merupakan salah satu potensi yang turut serta membangun perekonomian Indonesiamenjadi lebih baik. Hal itu juga menjadi faktor berkembangnya kegiatan usaha di bidang pertambangan nasional. Banyak perusahaan akhirnya memilih untuk bergelut di bidang pertambangan karena melihat keuntungan yang mereka dapatkan dari banyaknya kebutuhan dan permintaan dunia 
akan bahan mentah tambang. Di Indonesia terdapat 41 perusahaan bergerak di bidang pertambangan yang telah terdaftar di Bursa Efek Indonesia, sama seperti jenis perusahaan yang lainnya perusahaan tambang diwajibkan melakukan corporate social responsibility (CSR) atau tanggung jawab sosial perusahaan.

Corporate social responsibility (CSR) merupakan sebuah gagasan yang menjadikan tanggung jawab perusahaan tidak lagi hanya berfokus kepada single bottom line yaitu nilai perusahaan atau yang biasa direfleksikan dalam kondisi keuangannya saja (Daniri, 2008). Kesadaran atas pentingnya CSR dilandasi pemikiran bahwa perusahaan juga memiliki kewajiban kepada pihak-pihak lain yang berkepentingan selain kewajiban-kewajiban ekonomi dan legal kepada pemegang saham. CSR menunjukkan bahwa tanggungjawabperusahaan harus berpijak pada triple bottom lines yaitu pada aspek sosial, lingkungan, dan keuangan (Rustiarini, 2011). Konsep CSR muncul dikarenakan terjadinya kerusakan yang diakibatkan oleh kegiatan operasional perusahaan, sehingga adanya tuntutan dan harapan dari masyarakat mengenai peran perusahaan terhadap lingkungan sekitar.

CSR diatur dalam Peraturan Pemerintah bahwa setiap perseroan atau entitas yang berbadan hukum memiliki tanggungjawab sosial dan lingkungan (Pemerintah Republik Indonesia No 47 Tahun 2012). Hal tersebut juga ditegaskan dalam UU No. 40 Tahun 2007 Tentang Perseroan Terbatas. Pasal 74 ayat satu dari undang-undang tersebut berbunyi "Perseroan yang menjalankan kegiatan usahanya dibidang dan/atau berkaitan dengan sumber daya alam wajib melaksanakan Tanggungjawab Sosial dan Lingkungan”. Juga disebutkan bahwa CSRmerupakan kewajiban perseroan yang dianggarkan dan diperhitungkan sebagai biaya perseroan yang pelaksanaannya dilakukan dengan memperhatikan kepatuhan dan kewajaran.

Permasalahan-permasalahan sosial yang dihadapi oleh perusahaan di Indonesia terjadi karena lemahnya penegakan peraturan tentang tanggungjawab sosial perusahaan, misalnya tentang aturan ketenagakerjaan, pencemaran lingkungan, perimbangan bagi hasil suatu industri dalam era otonomi daerah (Putra, 2011). Pernyataan Standar Akuntansi Keuangan (PSAK) No.1 (revisi 2009) paragraf 12 menjelaskan pengungkapan CSR melalui laporan tahunan perusahaan kepada publik masih bersifat sukarela. Pengungkapan informasi sosial yang belum diwajibkan dalam PSAK menimbulkan praktik pengungkapkan informasi yang dilakukan oleh perusahaan umumnya bersifat sukarela (voluntary), belum diaudit (unaudited), dan tidak dipengaruhi oleh peraturan tertentu (unregulated) (Putra, 2011).

Penelitian mengenai faktor-faktor yang mempengaruhi pengungkapan tanggung jawab sosial perusahaan juga berkembang dengan dimasukkannya variabel-variabel yang dianggap berpengaruh yaitu media. Media menyediakan informasi bagi perusahaan dan dapat pula sebagai alat publikasi serta sosialisasi yang digunakan oleh perusahaan Andriany, dkk (2017). Media telah banyak digunakan oleh perusahaan pada saat ini untuk menyediakan informasi. Bentukbentuk informasi yang bisa dikomunikasikan perusahaan melalui media salah satunya adalah kegiatan corporate social responsibility yang dilakukan perusahan. Pengkomunikasian CSR melalui media akan meningkatkan reputasi perusahaan di mata masyarakat.

Pemerintah mengeluarkan peraturan yang terkait tanggungjawab sosial, yang diatur dalam Undang-Undang No. 40 tahun 2007 pasal 74 tentang tanggungjawab sosial dan lingkungan dan Peraturan Pemerintah No. 47 tahun 2012 pasal 2. Peraturan di atas menunjukkan bentuk kepedulian pemerintah terhadap masalah-masalah sosial yang merupakan bentuk pertanggungjawaban sosial perusahaan, tetapi belum ada standar mengenai seberapa banyak tanggungjawab sosial yang harus diungkap. Nurkhin (2009) menemukan bahwa tingkat pengungkapan CSR di Indonesia tergolong masih rendah. Standar pengungkapan CSR bagi 
dewan direksi perusahaan yang belum memilikiacuan menjadi salah satu penyebab dari hal tersebut.

Standar pengungkapan CSR yang berkembang di Indonesia merujuk pada standar yang diterapkan Global Reporting Initiative (GRI) G4. Standar ini lebih fokus pada standar pengungkapan sebagai kinerja ekonomi, sosial, dan lingkungan perusahaan dengan tujuan untuk meningkatkan kualitas dan pemanfaatan sustainability report. Dalam standar GRI-G4, indikator berdasarkan aspek terdiri menjadi tiga kategori, yaitu ekonomi, lingkungan hidup dan sosial yang mencakup hak asasi manusia, praktek ketenagakerjaan dan lingkungan kerja,tanggungjawab produk dan masyarakat.

Salah satu aspek GRI yaitu lingkungan, menjelaskan bagaimana perusahaan mengelola lingkungan hidup di kawasan industrinya. Oleh sebab itu Kementarian Lingkungan Hidup melakukan Program Penilaian Peringkat Kinerja Perusahaan Dalam Lingkungan Hidup (PROPER) dimana program ini memberikan penilaian pada perusahaan dalam mengelola lingkungan hidup yang terdampak oleh perusahaan dalam bentuk peringkat. Dasar hukum pelaksanaan PROPER adalah Keputusan Menteri Lingkungan Hidup Nomor:127/MENLH/2002 tentang Program Penilaian Peringkat Kinerja Perusahaan dalam Pengelolaan Lingkungan (PROPER), kemudian diperbaharui melalui penerbitan Keputusan Menteri Lingkungan Hidup Nomor: 250 tahun 2004 tentang Perubahan atas Keputusan Mentri Nomor: 127/MENLH/2002tentang Program Penilaian Peringkat Kinerja Perusahaan dalam Pengelolaan Lingkungan Hidup. Badan Pengendalian Dampak Lingkungan (Bapedal) mengukur kinerja lingkungan perusahaan-perusahaan yang beroperasi di wilayah hukum Indonesia, kemudian melaporkan hasilnya melalui konferensi pers maupun internet dalam bentuk laporan warna yang diberikan.

Peringkat kinerja penataan perusahaan PROPER dikelompokkan dalam lima peringkat warna yang masing-masing mencerminkan kinerja perusahaan. Kinerja penataan terbaik dilambangkan dengan warna emas, dan hijau, selanjutnya biru, merah dan kinerja terburuk dilambangkan dengan warna hitam. Melalui peringkat ini masyarakat akan lebih mudah memahami kinerja penataan masing-masing perusahaan. Secara eksplisit, PROPER dinilai dapat mendorong perusahaan di Indonesia untuk tidak hanya berfokus dalam meraup keuntungan semata, melainkan juga memperhatikan aspek kelestarian lingkungan dan pemberdayaan masyarakat di wilayah operasi perusahaan. PROPER juga dianggap membuat program CSR perusahaan lebih terencana dan tidak lagi berbasis sumbangan atau charity semata.

PROPER membuka informasi kepada publik mengenai tingkat kepatuhan lingkungan. Kebijakan PROPER menampilkan prestasi kerja perusahaan dibidang lingkungan hidup yang merupakan suatu bentuk tanggung jawab perusahaan kepada masyarakatnya. Dengan melaksanakan PROPER perusahaan akan mendapatkan insentif berupa penghargaan dari stakeholder juga citra positif dari masyarakat yang akan menaikan nilai perusahaan apabila mendapatkan peringkat yang baik dan itupun terjadi sebaliknya apabila perusahaan mendapat peringkat yang buruk maka perusahaan akan mendapatkan tekanan dari stakeholder dan juga citra yang buruk dari masyarakat yang secara tidak langsung akan menurunkan nilai perusahaan.

Teori legitimasi menyatakan bahwa perusahaan melakukan operasional perusahaan secara terus menerus sesuai dengan batas-batas dan nilai yang diterima oleh masyarakat di sekitar perusahaan untuk mendapatkan legitimasi. Masyarakat dalam hal ini diwakili oleh pemerintahan yaitu Menteri Lingkungan Hidup dengan mengeluarkan penilaian pengelolaan lingkungan hidup perusahaan dalam PROPER. Jadi perusahaan mengikuti PROPER untuk mendapatkan legitimasi dari masyarakat. 
Pengungkapan CSR yang dilakukan perusahaan melalui tiga kategori yaitu ekonomi, lingkungan hidup, dan sosial. Semua pengungkapan tersebut tidak diaudit berdasarkan PSAK No.1 (revisi 2009) paragraf 12 yang berarti pengungkapan tersebut belum tentu benar. Berdasarkan undang-undang dan peraturan pemerintah yang mengatur tentang pengungkapan CSR, perusahaan belum ada acuan dalam pengungkapan tersebut sehingga perusahaan bebas untuk mengungkapkan hal-hal terkait kegiatan dan pengelolaan perusahaan. Oleh sebab itu dengan adanya GRI sebagai pedoman yang membantu pengguna laporan untuk memahami penyajian dari laporan tersebut, begitu juga dengan adanya PROPER.

Salah satu perusahaan yang konsisten menyampaikan Laporan Keberlanjutan (Sustainability Report) adalah PT. Aneka Tambang Tbk (PT. ANTAM Tbk). Perusahaan ini telah membuat Sustainability Report sejak 2005, dan pada tahun 2006 PT.ANTAM mulai menggunakan GRI sebagai pedoman dalam menyusun Sustainability Report (Ariwendha dan Dede, 2015). PT. ANTAM adalah perusahaan yang menjalankan kegiatan usaha berkaitan dengan sumber daya alam khususnya tambang yang terbentuk sejak tahun 1968. Adapun kegiatan yang dijalankan yaitu perdagangan, pengangkutan, dan jasa yang berkaitan dengan pertambangan berbagai jenis bahan galian tambang tersebut. PT.ANTAM juga merupakan salah satu perusahaan yang mendapat peringkat yang baik (emas dan hijau) dalam penilaian kinerja lingkungannya yang diukur PROPER.

Penelitian terdahulu diteliti oleh Sari (2014) yang berjudul Analisis Pengungkapan Corporate Social Responsibility Berdasarkan Global Reporting Initiatives (GRI): Studi Kasus Perusahaan Tambang Batubara Bukit Asam (Persero) Tbk Dan Timah (Persero) Tbk. Analisis dilakukan terhadap penyajian indikator kinerja ekonomi, indikator kinerja lingkungan hidup, indikator kinerja praktik ketenagakerjaan dan lingkungan kerja, indikator kinerja hak asasi manusia, indikator kinerja masyarakat, indikator kinerja tanggungjawab produk yang dilaporkan dengan ketentuan yang ditetapkan GRI G.3.1. Hasil penelitian tersebut PT. Aneka Tambang Tbk dan PT. Timah Tbk telah mengungkapkan Corporate Social Responsibility (CSR) sesuai dengan GRI G3.1. Batubara Bukit Asam (Persero) Tbk dan Timah (Persero) Tbk telah mengungkapan setiap indikator kinerja dan pengungkapan rata-rata sudah melebihi $75 \%$. Namun pengungkapan indikator dan masing aspek aspeknya belum rinci.

Juga penelitian oleh Maroza (2016) dengan judul analisis pengungkapan sustainability report pada PT. Aneka Tambang Tbk dan PT. Vale Indonesia Tbk Tahun 2013-2014. Analisis dilakukan untuk mengukur tingkat pengungkapan indikator kinerja ekonomi, sosial dan lingkungan pada sustainability report terhadap 2 sampel perusahaan di Industri Tambang yaitu PT. ANTAM dengan pengungkapkan sebesar 48 komponen indikator pada tahun 2013 $(52,75 \%)$ dan 46 komponen indikator pada tahun 2014 (50,55\%) dan PT Vale Indonesia mengungkapkan sebesar 29 komponen indikator pada tahun $2013(31,87 \%)$ dan 34 komponen indikator pada tahun 2014 (37,37\%) dari komponen indikator GRI G4 Guidelines.

Berbeda dengan penelitian Sari (2014), yang mengalisa penyajian enam indikator kinerja yang dilaporkan dengan ketentuan yang ditetapkan GRI G.3.1, penelitian ini akan menganalisis indikator kinerja ekonomi, indikator kinerja lingkungan, indikator kinerja praktek ketenagakerjaan dan kenyamanan bekerja, indikator hak asasi manusia, indikator kinerja masyarakat, dan indikator kinerja tanggungjawab atas produk yang dilaporkan berdasarkan ketentuan GRI G.4 pada PT. ANTAM (Persero) Tbk. dimana Global Reporting Initiatives Generasi 4 ini merupakan generasi terbaru dalam sejarah GRI sebagaimana yang telah dilakukan dalam penelitian Maroza (2016). Dengan aspek indikator yang lebih banyak dibandingkan generasi sebelumnya, dan dalam penelitian kali ini juga akan membahas mengenai tingkat 
persamaan setiap indikator dalam Global Reporting Initiatives G.4 dengan PROPER yang diterbitkan oleh Kementerian Lingkungan Hidup, maka peneliti mengambil judul "Analisis Pengungkapan Corporate Social Responsibility Perusahaan Aneka Tambang (Persero) TBK. Berdasarkan Global Reporting Initiatives (GRI) dan Kaitannya Terhadap PROPER”.

\section{REVIU LITERATUR DAN PENGEMBANGAN HIPOTESIS \\ Teori Legitimasi}

Teori legitimasi merupakan teori yang melandasi Corporate Social Responsibility(CSR) atau Tanggungjawab Sosial. Dasar teori ini adalah organisasi atau perusahaan dianjurkan untuk meyakinkan bahwa aktivitas dan kinerjanya dapat diterima, agar masyarakat menyadari bahwa perusahaan beroperasi untuk sistem nilai masyarakat itu sendiri sehingga keberadaannya akan terus berlanjut. Teori legitimasi menjelaskan bahwa perusahaan secara terus-menerus akan beroperasi sesuai dengan batas-batas dan nilai yang diterima oleh masyarakat disekitar perusahaan dalam usaha untuk mendapatkan legitimasi. Legitimasi digambarkan sebagai tindakan yang dilakukan oleh suatu entitas atas dasar keinginan sendiri, sesuai dengan sistem dan norma serta kepercayaan yang berkembang di tatanan sosial masyarakat. (Rustiarini, 2011).

Legitimasi sangat penting bagi sebuah organisasi, batasan-batasan yang ditekankan oleh norma-norma dan nilai-nilai sosial, reaksi terhadap batasan tersebut mendorong pentingnya analisis perilaku organisasi dengan memperhatikan lingkungan (Dowling dan Preffer dalam Ghozali dan Chariri, 2007). Legitimasi merupakan sistem pengelolaan perusahaan yang berorientasi pada keberpihakan terhadap masyarakat, pemerintah, individu dan kelompok masyarakat. Dasar pemikiran teori ini adalah organisasi atau perusahaan akan terus berlanjut keberadaannya jika masyarakat menyadari bahwa organisasi beroperasi untuk sistem nilai yang sepadan dengan sistem nilai masyarakat itu sendiri (Gray et al dalam Ahmad dan Sulaiman, 2004 dikutip dalam Erdanu, 2010).

Perusahaan dianjurkan untuk meyakinkan masyarakat bahwa aktivitas dan kinerjanya dapat diterima. Laporan Tahunan digunakan oleh perusahaan untuk menggambarkan kesan tanggungjawab lingkungan, sehingga mereka diterima oleh masyarakat. Dengan adanya penerimaan dari masyarakat tersebut diharapkan mampu meningkatkan nilai perusahaan sehingga dapat menaikan laba perusahaan serta mendorong atau membantu investor dalam melakukan pengambilan keputusan investasi. Teori legitimasi menjelaskan tentang pengakuan masyarakat, perusahaan membutuhkan pengakuan masyarakat dengan cara mengungkapkan dan menerapkan CSR agar perusahaan dapat diterima dengan baik oleh masyarakat. Diterimanya suatu perusahaan oleh masyarakat, merupakan suatu bentuk legalitas bagi perusahaan. Pengungkapan Corporate Social Resposibility oleh perusahaan memberikan image positif dimata para stakeholdernya, sehingga dapat menunjang keberlangsungan hidup perusahaan tersebut (Amalia, 2016).

Jadi berpedoman dengan teori legitimasi ini, perusaan harus menerapkan dan melaksanakan kegiatan CSR agar menerima kesan positif dari masyarakat sekitar sehingga kegiatan operasional perusahaan dapat berjalan dengan lancar dan masyarakat tetap merasa nyaman dan tidak terganggu dengan keberadaan dan aktivitas perusahaan.

\section{Laporan Keberlanjutan (Sustainability Report)}

Laporan keberlanjutan (sustainability report) adalah sebuah pelaporan yang dilakukan oleh perusahaan untuk mengukur, mengungkapkan (disclouse), serta upaya perusahan untuk menjadi perusahaan yang akuntabel bagi seluruh pemangku kepentingan (stakeholder) untuk tujuan 
kinerja perusahaan menuju pembangunan yang berkelanjutan. Sustainability report adalah istilah umum yang dianggap memiliki kesamaan untuk menjelaskan laporan pertanggungjawaban perusahaan, laporan perusahaan yang meggambarkan dampak ekonomi, lingkungan, dan sosial (misalnya triple bottom line, dan lain sebagainya) (Global Reporting Initiative, 2006).

Sustainability Report memiliki definisi yang beragam, menurut Elkington (dalam Tarigan dan Semuel, 2014), Sustainability Report berarti laporan yang memuat tidak saja informasi kinerja keuangan tetapi juga informasi non keuangan yang terdiri dari informasi lingkungan dan aktivitas sosial yang memungkinkan perusahaan bisa bertumbuh secara berkesinambungan (Sustainable Performance). Berdasarkan Undang-undang No. 40 Tahun 2007 tentang Perseroan Terbatas pasal 66 ayat 2 yang mengamanatkan perusahaan yang telah go public memiliki kewajiban membuat sustainability report.

\section{Laporan Tahunan (Annual Report)}

Laporan tahunan (annual report) merupakan laporan perkembangan dan pencapaian yang diraih oleh sebuah organisasi dalam satu tahun dengan menggunkan data yang akurat sebagai dasar dalam penyusunan laporan. Annual report sendiri terdiri atas segala macam bentuk informasi tentang perusahaan, tidak hanya berkutat pada hightlight keuangan saja, namun lebih memuat perihal segala macam bentuk kegiatan perusahaan, strategi serta perjalanan bisnis perusahaan dalam satu tahun berjalan dan lain sebagainya.

\section{Pengungkapan Corporate Sosial Responsibility(CSR)}

Corporate Social Responsibility (CSR) merupakan tindakan sosial yang dituntut atau diharuskan dalam peraturan perundang-undangan, agar perusahaan peduli terhadap lingkungan hidup yang lebih dari batas-batas sebagaimana.CSR adalah suatu komitmen bisnis untuk turut berkontribusi dalam membangun ekonomi berkelanjutan. European Commission (dalam Weber, 2008) mendefinisikan CSR sebagai sebuah konsep di mana perusahaan memutuskan secara sukarela berkontribusi untuk masyarakat yang lebih baik dan lingkungan yang lebih bersih dengan mengintegrasikan persoalan sosial dan lingkungan ke dalam operasi bisnis mereka dan dalam interaksi mereka dengan stakeholder mereka.

Tanggungjawab sebuah organisasi terhadap dampak-dampak dari keputusan-keputusan dan kegiatan-kegiatan pada masyarakat dan lingkungan yang diwujudkan dalam bentuk perilaku transparan dan etis yang sejalan dengan pembangunan berkelanjutan dan kesejahteraan masyarakat (ISO 26000, draft 3, 2007).Berdasarkan pengertian tersebut, CSR adalah tanggungjawab perusahaan dalam bentuk kepedulian perusahaan dengan menyisihkan keuntungan untuk mensejahterakan masyarakat dan lingkungan serta berkonstribusi dalam laporan keberlanjutan.

John Elkingtonpada tahun 1997 melalui bukunya "Cannibals with Forks, the Triple Bottom Line of Twentieth Century Business" mengenalkan istilah triple bottom line. Elkington mengembangkan konsep triple bottom line dalam istilah economic prosperity, environmental quality dan social justice. Elkington memberi pandangan agar suatu perusahaan dapat berkelanjutan keberadaanya maka perusahaan tersebut sebaiknya tidak hanya mengejar profit, perusahaan juga harus memperhatikan dan terlibat dalam pemenuhan kesejahteraan masyarakat (people) serta turut berkontribusi aktif dalam menjaga kelestarian lingkungan (planet) (Wibisono (2007). Respati (2015) menyatakan bahwa pengungkapan media adalah cara perusahaan mengkomunikasikan identitas serta informasi mengenai kegiatan yang dilakukan oleh perusahaan dengan memanfaatkan media yang telah tersedia. Suatu perusahaan bisa 
mengkomunikasikan kegiatan-kegiatannya dengan memanfaatkan berbagai media, salah satu kegiatan yang bisa dikomunikasikan adalah pengungkapan lingkungan perusahaan.

\section{Global Reporting Initiatiatives (GRI)}

Global Reporting Initiatives (GRI) merupakan sebuah pedoman laporan keberlanjutan (Sustainability Report). GRI adalah sebuah kerangka pelaporan untuk membuat Sustainability Report yang terdiri atas prinsip-prinsip pelaporan, panduan pelaporan dan standar pengungkapan (termasuk didalamnya indikator kinerja). Elemen-elemen ini dipertimbangkan dengan memiliki kepentingan dan bobot yang sama untuk penilaiannya, (GRI,2013). Pedoman ini juga menyediakan referensi internasional untuk semua pihak yang terlibat degan pengungkapan pendekatan tata kelola serta kinerja dan dampak lingkungan, sosial serta ekonomi perusahaan (Ladina, Wijono dan Nila, 2016).

\section{PROPER}

PROPER adalah salah satu instrumen kebijakan yang dikembangkan oleh Kementerian Negara Lingkungan Hidup (KLH) sejak tahun 1995 yang merupakan singkatan dari Program Penilaian Peringkat Kinerja Perusahaan dalam Pengelolaan Lingkungan merupakan. Bertujuan untuk mendorong untuk mendorong penataan dan kepedulian perusahaan dalam

\section{METODE PENELITIAN}

\section{Jenis Penelitian}

Jenis penelitian ini adalah penelitian kualitatif deskriptif. Penelitian kualitatif adalah penelitian yang berlandaskan pada filsafat postpositivisme,digunakan untuk meneliti pada kondisi objek yang alamiah,dimana peneliti adalah sebagai instrument kunci.

\section{Objek Penelitian}

Dalam penelitian ini, yang menjadi objek penelitian adalah laporan tahunan (annual report) dan laporan berkelanjutan (sustainability report) PT. Aneka Tambang Tbk tahun 2016-2017.

\section{Jenis, Sumber dan Teknik Pengumpulan Data}

Jenis data dalam penelitian ini adalah data sekunder. Data sekunder adalah jenis data yang diperoleh peneliti dari sumber yang telah ada. Data yang digunakan adalah Laporan tahunan perusahaan (annual report) dan Laporan berkelanjutan perusahaan (sustainability report) yang berdasarkan GRI G.4. yang diambil dari laman resmi masing perusahaan (www.antam.com).

Sumber data dalam penelitian ini adalah data dokumenter, berupa laporan tahunan (annual report)dan Laporan berkelanjutan (sustainability report) tahun 2017-2018 PT. Aneka Tambang. Dalam Laporan tahunan (annual report) dan laporan berkelanjutan (sustainability report) PT. Aneka Tambang terdapat pengungkapan informasi mengenai program CSR perusahaan yang disampaikan kepada publik, ditambah lagi dengan beberapa berita yang berhubungan dengan aktivitas PT. Aneka Tambang yang diperoleh dari media online. Teknik pengumpulan data padapenelitian ini adalah domkumenter, studi pustaka, internet searching. 


\section{Teknik Analisis Data}

\section{a. Coding}

Tahap yang dilakukan pertama adalah checklist untuk mengukur narasi pengungkapan sustainability reporting perusahaan yaitu kategori tiap indikator sesuai dengan itemitem mengacu GRI G4 (Fourth Generation) Guideliness yang baru dikeluarkan pada tahun 2013.

1) Kode 0 jika sama sekali tidak mengungkapkan dalam sustainability report.

2) Kode 1 jika terdapat satu item yang diungkapkan dalam sustainability report. Setelah dilakukan checklist pada pengungkapan sustainability report kemudian pengungkapan tersebut, dibahas dan dianalisis berdasrakan indikator ekonomi, indikator lingkungan dan indikator sosial. Masing- masing indikator dianalisis menurut perusahaan pada tahun sustainability report di terbitkan.

\section{b. Scorings}

Untuk mengetahui tingkat pengungkapan indeks kinerja maka dilakukan scoring atas item-item yang diungkapkan dalam sustainability report dengan rumus sebagai berikut:

$$
\text { Tingkat pengungkapan }=\frac{\text { Jumlah pengungkapan yang dipenuhi }}{\text { Jumlah skor item maksimum }} \times 100 \%
$$

Selanjutnya dilakukan analisis pengungkapan sustainability report untuk diketahui skor dari komponen masing-masing indikator dalam bentuk:

1) Naratif (Penjabaran) : dengan nilai skor sebesar 1.

2) Grafik/Tabel : dengan nilai skor sebesar 2.

3) Non-moneter (hal yang tidak berhubungan dengan keuangan, seperti hari, orang, kg, meter, hektar) : dengan nilai skor sebesar 3.

4) Moneter (hal yang berhubungan dengan keuangan): dengan nilai skor sebesar 4.

Teknik skor tersebut digunakan agar terdapat kelengkapan dan informasi yang komprehensif dalam sustainability reporting. Bentuk Moneter dengan skor tertinggi dimaksudkan karena lebih mudah untuk membandingkan dengan bentuk yang lain (fleksibel) (Akbar, 2008).

\section{c. Pengelompokan Kategori}

Dari skor tersebut dikelompokkan dalam kategori menurut Chapman and Milne (2003), yaitu dalam tabel sebagai berikut :

Tabel 1.

Pengelompokan Kategori

\begin{tabular}{|c|c|}
\hline Kategori & Skor \\
\hline Ober the Horizon & $141-194$ \\
Traiblazers & $121-140$ \\
NewBenchmarks & $101-120$ \\
State-of the-Art & $81-100$ \\
Pressing Hard & $61-80$ \\
Not So Hot & $41-60$ \\
Ultra Narrow & $21-40$ \\
Bottom Crawler & $1-20$ \\
\hline \multicolumn{2}{|c|}{ Sumber: Chapman and Milne (2003) }
\end{tabular}




\section{HASIL DAN PEMBAHASAN}

Hasil penelitian ini menunjukan bahwa perushaan ANTAM telah melakukan dan melaporkan kegiatan CSR dengan baik. Dari hasil coding item-item indikator pengungkapan pada tahun 2017 dan 2018 dengan 3 aspek kinerja. Ketiganya menggambarkan stakeholder bagaimana bentuk pertanggungjawaban perusahaan kepada para terhadap kinerja ekonomi, sosial dan lingungan dalam kegiatan operasional perusahaan.

Temuan dari analisis ini menunjukan bagaimana ANTAM dalam membentuk pelaporan ekonomi, lingkungan dan sosial. Dari 3 indikaror dalam Sustainability Report ANTAM di tahun 2017 dan 2018 pada tabel 4 menjelaskan bahwa indikator kinerja lingkungan diungkapkan dengan persentase paling tinggi dibandingkan dengan indikator ekonomi maupun sosial. Tingkat kedua tertinggi merupakan indikator sosial dan indikator ekonomi menempatkan indikator dengan persentase pengungkapan terendah. Berikut adalah penyajian tingkat pengungkapan CSR pada tahun 2017 dan 2018 berdasarkan indikator dalam bentuk grafik.

Grafik 2.

Pengungkapan Komponen Kinerja ANTAM Berdasarkan Global Reporting Initiatives pada Tahun 2017 dan 2018

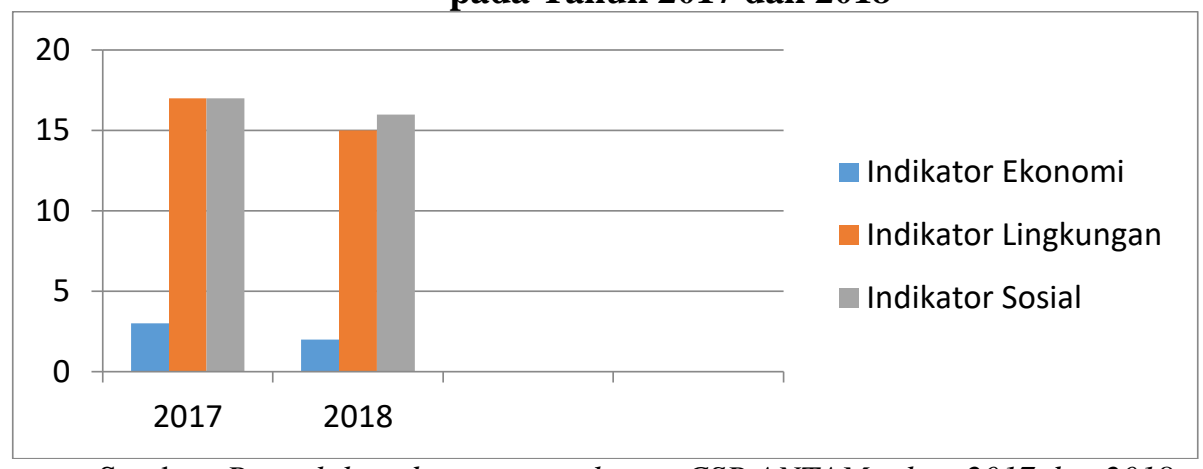

Sumber: Pengolahan data pengungkapan CSR ANTAM tahun 2017 dan 2018

Dari grafik diatas, dapat dilihat pengungkapan CSR ANTAM berdasarkan Global Reporting Initiatives G.4 Guidelines lebih banyak diungkapkan pada tahun 2017 dari pada di tahun 2018 sejalan pula dengan penurunan peringkat PROPER yang diterima ANTAM pada tahun 2017 yaitu emas, menurun menjadi Hijau ditahun 2018. Penurunan pengungkapan indikator ekonomi pada ANTAM ini diduga karena terjadi kenaikan total laba usaha tahun 2018 sebesar Rp1,85 triliun, tumbuh sebesar 208\% dari laba usaha sebesar Rp. 600,61 miliar pada tahun 2017. Capaian laba ini terjadi karena pertumbuhan penjualan atas seluruh produk komoditas ANTAM pada tahun 2018 naik sebesar 99\%.. Dan hal ini sejalan dengan penelitian oleh Felicia dan Ni Ketut (2015), Susilatri dan Indriani (2011), Wijaya (2012) dan Caroll (1991) yang menyatakan bahwa profitabilitas yang digambarkan oleh penjualan yang signifikan terhadap pengungkapan tanggung jawab sosial atau CSR. Hal ini disebabkan karena perusahaan yang mempunyai profitabilitas yang tinggi belum tentu melakukan pengungkapan CSR karena perusahaan lebih berorientasi pada laba.

Sedangkan untuk perhitungan skoring dalam pengungkapan CSR ANTAM pada tahun 2017 sebesar 137 sedangkan pada tahun 2018 sebesar 110. Dengan pengungkapan terbanyak tahun 2017 dalam bentuk non- moneter, sedangkan indikator komponen terbesar yaitu indikator kinerja lingkungan. Pada tahun 2018 pengungkapan terbanyak juga dalam bentuk non-moneter dengan indikator komponen terbesar juga indikator kinerja lingkungannya. Dari total skor tersebut, dikelompokkan kembali berdasarkan kategori pada semua tabel, untuk mengetahui 
tingkat keluasan dan kedalaman (breadth and depth) Sustainability Report masing-masing perusahaan sebagaiberikut serta dapat dilihat pada Grafik 3:

Grafik 3.

Tingkat Keluasan dan Kedalaman CSR tahun 2017 dan 2018 ANTAM

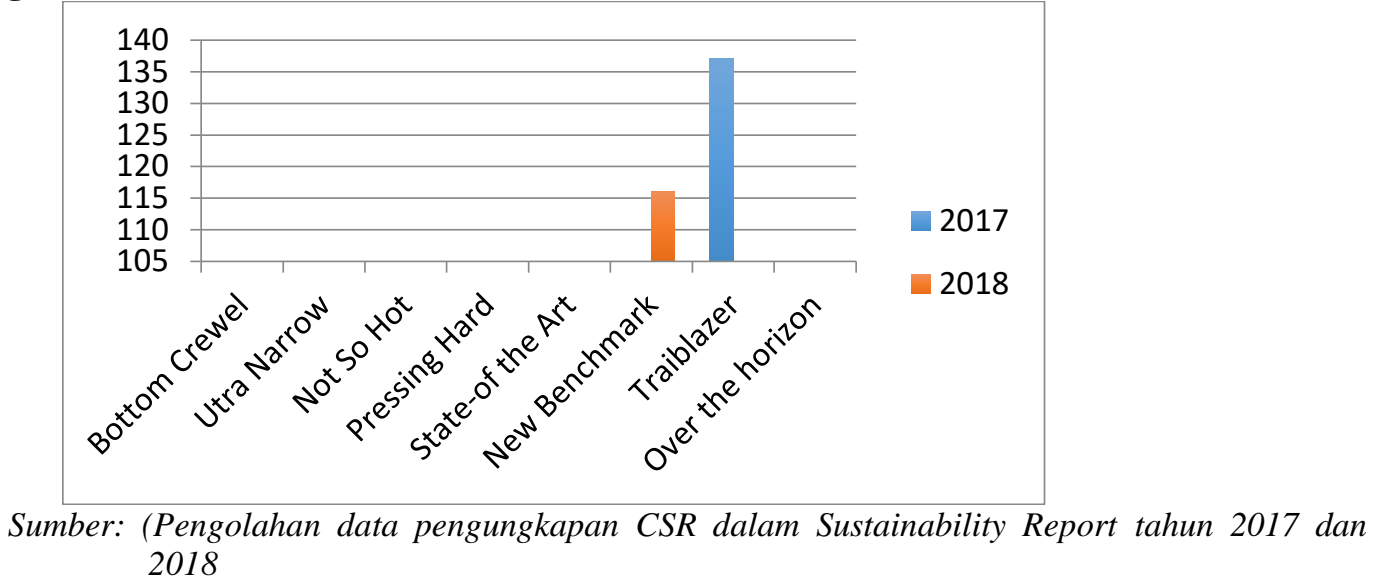

Hasil dari pengelompokkan kategori tingkat keluasan dan kedalaman dari perusahaan ANTAM tahun 2017 adalah Traiblazer merupakan kategori yang menunjukan bahwa perusahaan tersebut telah beroperasi dengan baik dengan nilai 121-140 dan sebagai jalan untuk mendapati kategori paling tinggi yaitu over the horizon. Sedangkan hasil untuk tahun 2018 mengalami penurunan menjadi New Bencmark yang merupakan kategori yang menunjukan perusahaan harus lebih giat lagi mengungkapkan tingkat keluasan dan kedalaman di bidang ekonomi, lingkungan dan sosial agar dapat berkembang lebih baik dan dapat mendorong untuk mendapatkan skor lebih tinggi.

Dari pembahasan dan analisis yang telah dijelaskan penelitian ini menunjukkan bahwa ANTAM sebagai perusahaan BUMN memiliki tingkat pengungkapan lebih tinggi ditahun 2017 dan menurun pada tahun 2018. Hal ini ANTAM dapat dikatakan sebagai perusahaan yang sudah mengungkapkanCSRmeliputi kinerja ekonomi, kinerja lingkungan dan kinerja sosial dengan baik dengan pedoman GRI tebaru yaitu GRI G4, tetapi tetap harus memperhatikan serta meningkatkan pengungkapan CSR setiap tahunnya agar tidak selalu terjadi penurunan.

\section{PEMBAHASAN}

\section{Analisis Pengungkapan CSR ANTAM Tahun 2017 dan 2018}

Berdasarkan kepada hasil analisis pengungkapan CSR ANTAM berdasarkan Global Reporting Initiatives G.4 Guidelines lebih banyak diungkapkan pada tahun 2017 dari pada di tahun 2018. Berikut disajikan tingkat pengungkapan CSR dari ANTAM pada tahun 2017 dan 2018 berdasarkan indikator dalam bentuk tabel yaitu: 
Tabel 2.

Tingkat Pengungkapan CSR Berdasarkan Masing - Masing Indikator

\begin{tabular}{|c|c|c|c|c|c|c|}
\hline \multirow{3}{*}{ Keterangan } & \multirow{3}{*}{$\begin{array}{l}\text { Total } \\
\text { Item }\end{array}$} & \multirow[b]{3}{*}{$\%$} & \multicolumn{4}{|c|}{ Tahun } \\
\hline & & & \multicolumn{2}{|c|}{2017} & \multicolumn{2}{|c|}{2018} \\
\hline & & & & $\%$ & & $\%$ \\
\hline Indikator Ekonomi & 9 & $10 \%$ & 3 & $33,33 \%$ & 2 & $22,22 \%$ \\
\hline Indikator Lingkungan & 34 & $37 \%$ & 17 & $50 \%$ & 16 & $47,05 \%$ \\
\hline Indikator Sosial & 48 & $53 \%$ & 17 & $35,41 \%$ & 16 & $33,33 \%$ \\
\hline Total Pengungkapan & 91 & $100 \%$ & 37 & $40,66 \%$ & 34 & $37,39 \%$ \\
\hline
\end{tabular}

Berdasarkan tabel diatas dapat kita lihat tingkat pengungkapan CSR ANTAM tahun 2017 ke 2018 mengalami penurunan sebesar $3,27 \%$. Penurunan ini terjadi pada setiap indikator yang terdapat di GRI G.4, pada indikator ekonomi terjadi penurunan sebesar $11,11 \%$, pada indikator lingkungan terjadi penurunan sebesar 2,95\% dan pada indikator sosial terjadi penurunan sebesar 2,09\%. Pelaporan ini disajikan dengan lampiran, diikuti oleh pembahasan terhadap pengungkapan pada masing-masing indikator. Tabel 5 menunjukan ringkasan pengungkapan 3 indikator pengungkapan dan masing-masing akan dibahas berdasarkan GRI G4 Guidelines:

\section{Indikator Ekonomi}

Kategori kinerja ekonomi mempunyai 9 item indikator yang diungkapkan pada Sustainability Report. Pada tahun 2017 ANTAM mengungkapkan 3 item indikator dan tahun 2018 mengungkapkan 2 item indikator. Penurunan pengungkapan terjadi pada item indikator dampak ekonomi tidak langsung yang signifikan, termasuk besarnya dampak (G4-EC8). Item indikator ini tidak diungkapkan karenakan ANTAM tidak melakukan perubahan dampak ekonomi tidak langsung, yang pada tahun 2017 perusahaan telah berpartisipasi untuk meningkatkan kesejahteraan masyarakat terutama di sekitar wilayah operasi melalui infrastruktur yang signifikan dan memberikan pelayanan kemasyarakat melalui program-program pemberdayaan masyarakat (ComDev) dan Bina Lingkungan.

Untuk item indikator Implikasi finansial dan risiko serta peluang lainnya kepada kegiatan organisasi karena perubahan iklim (C4-EC2) tidak diungkapkan ditahun 2017 dan 2018, item ini terakhir di ungkapkan pada laporan 2016, tidak diungkapkan ditahun selanjutnya= karena tidak ada dampak dari perubahan iklim ditahun tersebut. Item indikator cakupan kewajiban organisasi atas program imbalan pasti (G4-EC3) juga tidak diungkapkan ditahun 2017 dan 2018, item ini terakhir kali diungkapkan pada tahun 2014 dan ditahun berikutnya tidak lagi ada pengungkapan tentang program imbalan pasti perusahaan. Untuk item indikator bantuan finansial yang diterima pemerintah, terakhir diungkapkan ditahun 2015 yang menyatakan bahwa ANTAM tidak menerima bantuan pendanaan dari pemerintah sehingga pada laporan tahun 2017 dan 2018 tidak lagi ditemukan pengungkapan, hal ini diduga karena pada tahun tersebut ANTAM juga tidak menerima bantuan finansial dari pemerintah sehingga merasa hal tersebut tidak perlu diungkapkan lagi.

Item indikator rasio upah standar pegawai pemula (entry level) menurut gender dibandingkan dengan upah minimun regional di lokasi-lokasi operasional yang signifikan (G4EC5), Perbandingan manajemen senior yang dipekerjakan dari masyarakat lokal di lokasi operasi yang signifikan (G4-EC6) dan perbandingan pembelian dari pemasok lokal di lokasi operasional yang signifikan (G4-EC9) juga tidak diungkapkan pada Sustainability Report ANTAM tahun 2017 dan 2018. Item ini juga tidak ditemukan pada tahun tahun sebelumnya diduga karena kegiatan tersebut memang tidak dilakukan oleh ANTAM sehingga perusahan merasa tidak perlu 
mengungkapkan dalam CSR nya.

\section{Indikator Lingkungan}

Indikator kinerja lingkungan mempunyai 34 item indikator yang diungkapkan pada Sustainability Report yang kemudian terbagi dalam 12 aspek yaitu, Bahan, energi, air, keanekaragaman hayati, emisi, efluen dan limbah, produk dan jasa, kepatuhan, transportasi, lainlain, asesmen pemasok atas lingkungan, mekanisme pengaduan masalah lingkungan. Perusahaan ANTAM pada tahun 2017 telah mengungkapkan 17 item indikator dan mengungkapkan 16 item indikator pada tahun 2018. Penurunan ini terjadi karena pada tahun 2018 tidak mengungkapkan item indikator jumlah total spesies dalam IUCN Red List dan spesies dalam daftar spesies yang dilindungi nasional dengan habitat di tempat yag dipengaruhi operasional, berdasarkan tingkat resiko kepunahan.

Dalam Sustainability Report tahun 2017 dijelaskan bahwa ANTAM telah melakukan identifikasi flora dan fauna yang ditemukan di sekitar area operasional. Identifikasi tersebut dilaksanakan sesuai dengan ketentuan dan persyaratan AMDAL. Identifikasi ini menjadi basis bagi perusahaan untuk melakukan pemantauan terhadap flora dan fauna untuk kemudian menentukan kebutuhan untuk konservasi atau program lain dalam rangka menjaga kelestarian mereka, sebagaimana yang terlampir dalam lampiran II tentang daftar jumlah spesies dalam IUCN Red List dan spesies dilindungi nasional yang habitatnya dipengaruhi oleh kegiatan operasional perusahaan. Sedangkan pada pengungkapan CSR tahun 2018 ANTAM tidak melakukan pengungkapan lagi, diduga karena ANTAM merasa hal tersebut telah diungkapkan pada laporan sebelumnya, tidak terdapat perubahan sehingga tidak perlu ungkapkan lagi.

ANTAM tidak mengungkapkan item indikator bahan yang digunakan berdasarkan berat atau volume (G4-EN1), dan persentase bahan yang digunakan yang merupakan bahan input dari daur ulang (G4-EN2) yang merupakan bagian dari aspek bahan pada kinerja lingkungan Sustainability Report tahun 2017 dan 2018. Dalam aspek energi, item indikator diluar organisasi, item indikator pengurangan konsumsi energi (G4-EN6) dan pengurangan kebutuhan energi pada produk dan jasa (G4-EN7).

Dalam aspek air perusahaan tidak mengungkapkan item indikator sumber air yang secara signifikan dipengaruhi oleh pengambilan air (G4-EN9) pada tahun 2017 dan 2018. Hal tersebut mungkin dikarenakan selama tahun bersangkutan ANTAM tidak pernah menerima laporan atau komplain dari masyarakat tentang terganggunya sumber air yang digunakan oleh Perusahaan,serta tidak pernah ada komplain dari masyarakat terhadap kualitas air yang dilepaskan oleh Perseroan. Dan ANTAM merasa dalam pengambilan air tidak ada sumber ditetapkan sebagai kawasan lindung secara nasional atau internasional, tidak mengganggu nilai atau pentingnya sumber air bagi masyarakat lokal dan masyarakat adat sehingga hal tersebut tidak perllu diungkapkan dalam laporan 2017 dan 2018.

Selanjutnya aspek keanekaragaman hayati perusahaan ANTAM tidak mengungkapkan item indiaktor uraian dampak signifikan kegiatan, produk, dan jasa terhadap keanekaragaman hayati di kawasan lindung dan kawasan dengan keanekaragaman hayati tinggi di luar kawasan lindung (G4-EN12) hal ini dikarenakan pada tahun 2017 dan 2018 kegiatan penambangan yang dilakukan perusahaan tidak berdampak signifikan terhadap keanekaragaman hayati dan habitat yang ada dikarenakan kegiatan penambangan dilakukan tertutup di dalam tanah.

Untuk aspek emisi ANTAM pada tahun 2017 dan 2018 tidak mengungkapkan item indikator emisi gas rumah kaca (GRK) tidak langsung lainnya - cakupan 3 (G4-EN17) dan emisi bahan perusak ozon (G4-EC20) dalam Sustainability Reportnya. Item indikator yang tidak 
diungkapkan pada aspek Efluen dan limbah selama dua tahun tersebut adalah bobot limbah yang dianggap berbahaya menurut ketentuan konvensi basel $^{2}$ lampiran I, II,III dan VIII yang diangkut, diimpor, diekspor atau diolah dan persentase limbah yang diangkut untuk pengiriman internasional (G4-EN25) serta indentitas, ukuran, status lindung dan nilai kenaekaragaman hayati dari badan air dan habitat terkait secara signifikan terkena dampak dari air buangan dan limpasan dari organisasi (G4-EN26) dikarenakan ANTAM juga memastikan kualitas air di badan air penerima seperti sungai dan tidak pernah menerima laporan dan pengaduan dari masyarakat maupun pihak berwenang terkait gangguan keanekaragaman hayati dan habitat di dalam badan air

ANTAM tidak mengungkapkan item indikator tingkat mitigasi dampak terhadap dampak lingkungan produk dan jasa (G4-EN27) dan persentase produk yang terjual dan kemasannya yang direklamasi menurut kategori (G4-EN28) dalam aspek produk dan jasa untuk kinerja lingkungan nya pada Sustainability Report tahun 2017 maupun 2018, karena ANTAM tidak memasukkan produk rusak dan yang ditarik kembali sehingga tidak adanya pengungkapan pada tahun tersebut. Untuk item indikator nilai moneter denda signifikan dan jumlah total sanksi nonmoneter karena ketidakpatuhan terhadap UU dan peraturan lingkungan (G4-EN29) dalam aspek kepatuhan telah diungkapkan oleh perusahaan baik pada tahun 2017 maupun 2018. Aspek transportasi dengan item indikator dampak lingkungan signifikan dari pengangkutan produk dan barang lain serta bahan untuk operasional organisasi, dan pengangkutan tenaga kerja (G4-EN30) dan aspek lain-lain dengan item indikator total pengeluaran dan investasi perlindungan lingkungan berdasarkan jenis (G4-EN31) tidak diungkapkan dalam dua tahun Sustainability Report ANTAM.

Selanjutnya aspek asesmen pemasok atas lingkungan item indikator persentase penapisan pemasok baru menggunakan kriteria lingkungan (G4-EN32) telah diungkapkan oleh ANTAM pada tahun 2017 maupun 2018 tetapi untuk item indikator dampak lingkungan negatif signifikan aktual dan potensial dalam rantai pemasok dan tindakan yang diambil tidak diungkapkan. Aspek terakhir yaitu mekanisme pengaduan masyarakat dengan item indikator jumlah pengaduan tentang dampak lingkungan yang diajukan, ditangani, dan diselesaikan melalui mekanisme pengaduan resmi (G4-EN34) tidak diungkapkan pada tahun 2017 maupun 2018.

\section{Indikator Sosial}

Indikator Kinerja Sosial mempunyai 48 item indikator yang diungkapkan dalam Sustainability Report, dimana item tersebut terbagi atas 4 sub-indikator yaitu: praktik ketenagakerjaan dan kenyamanan bekerja, hak asasi manusia, masyarakat, tanggung jawab atas produk. Sebagian besar konten sub-indikator didasarkan pada standar universal yang daikui secara internasional atau referensi internasional lainnya yang relevan.Berikut sajian tingkat pengungkapan CSR ANTAM untuk Indikator Sosial: 
Tabel 3.

Tingkat Pengungkapan CSRIndikator Sosial

\begin{tabular}{|c|c|c|c|c|c|c|}
\hline & & \multirow{3}{*}{$\begin{array}{l}\text { Total } \\
\text { Item }\end{array}$} & \multicolumn{4}{|c|}{ Tahun } \\
\hline & & & \multicolumn{2}{|c|}{2017} & \multicolumn{2}{|c|}{2018} \\
\hline \multicolumn{2}{|c|}{ Indikator Sosial } & & & $\%$ & & $\%$ \\
\hline 1 & $\begin{array}{l}\text { Praktik Ketenagakerjaan } \\
\text { dan kenyaman bekerja }\end{array}$ & 16 & 11 & $68,75 \%$ & 11 & $68,75 \%$ \\
\hline 2 & Hak Asasi Manusia & 12 & 1 & $8,33 \%$ & 1 & $8,33 \%$ \\
\hline 3 & Masyarakat & 11 & 4 & $36,36 \%$ & 3 & $27,27 \%$ \\
\hline 4 & Tanggung Jawab Produk & 9 & 1 & $11,11 \%$ & 1 & $11,11 \%$ \\
\hline & Total & 48 & 17 & $35,41 \%$ & 16 & $33,33 \%$ \\
\hline
\end{tabular}

Berdasarkan tabel pengungkapan CSR Indikator Sosial diatas, dapat kita ketahui subindikator praktik ketenagakerjaan dan kenyamanan bekerja memiliki persentase pengungkapan tertinggi, yaitu $68,75 \%$ pada tahun 2017 dan 2018. Sub-indikator masyarakat memiliki persentase pengungkapan sebesar 36,36\% pada tahun 2017 dan terjadi penurunan menjadi $27,27 \%$ pada tahun 2018, sub-indikator hak asasi manusia sebesar 8,33\% serta tanggung jawab atas produk sebesar 11,11\% baik pada tahun 2017 maupun 2018.

\section{Sub- indikator Praktik ketenagakerjaan dan kenyaman bersama}

Pada sub-indikator ini terdiri dari beberapa aspek diantaranya kepegawaian, ANTAM tidak mengungkapkan item indikator tingkat kembali bekerja dan tingkat retens setelah cuti melahirkan, menurut gender (G4-LA3) pada tahun 2017 dan 2018 hal ini diduga dianggap tidak perlu diungkapkan karena sebagian besar karyawan atau pekerja ANTAM adalah laki-laki. Selanjutnya aspek hubungan industrial dengan item indikator jangka waktu minimum pemberitahuan mengenai perubahan operasional, termasuk apakah hal tersebut tercantum dalam perjanjian bersama (G4-LA4) juga tidak diungkapkan pada Sutainability Report ANTAM.

Perusahaan telah mengungkapkan seluruh aspek kesehatan dan keselamatan kerja yang terdiri dari 4 item indikator dengan sangatbaik dan jelas. Juga mengungkapkan aspek pelatihan dan pendidikan, spek keberagaman dan kesetaraan peluang, aspek kesetaraan remunerasi perempuan dan laki-laki pada Sustainability Report tahun 2017 dan 2018. Untuk aspek asesmen pemasok atas praktik ketenagakerjaan dengan item indikator persentase penapisan pemasok baru menggunakan kriteria praktik ketenagakerjaan (G4-LA14), dampak negatif aktual dan potensial yang signifikan terhadap praktik ketenagakerjaan dalam rantai pasokan dan tindakan yang diambil (G4-LA15) serta aspek mekanisme pengaduan masalah ketenagakerjaan dengan item indikator jumlah pengaduan tentang praktik ketenagakerjaan yang diajukan, ditangani, dan diselesaikan melalui mekanisme pengaduan resmi (G4-LA16) tidak diungkapkan pad Sustainability Report tahun 2017 maupun 2018.

\section{Sub - indikator Hak asasi manusia}

Berdasarkan tabel diatas, dapat kita lihat dalam sub-indikator hak asasi manusia terdiri dari 10 aspek, dan hanya 1 aspek yang diungkapkan dalam Sustanability Report tahun 2017 maupun 2018 yaitu aspek non-diskriminasi dengan item indikator jumlah total insiden diskriminasi dan tindakan perbaikan yang diambil (G4-HR3). Sedangkan aspek lainnya dalam pengungkapan CSR perusahaan ANTAM tidak ditemui. Adapun aspek tersebut yaitu, aspek investasi dengan item indikator jumlah total investasi dan persentase perjanjian dan kontrak investasi yang signifikan yang menyertakan klausul terkait hak asasi manusia atau penapisan berdasarkan hak asasi manusia (G4-HR1) dan jumlah waktu pelatihan karyawan tentang kebijakan atau prosedur 
hak asasi manusia terkait dengan aspek hak asasi manusia yang relevan dengan operasi, termasuk persentase karyawan yang dilatih (G4-HR2).

Aspek kebebasan berserikat dan perjanjian kerja bersama dengan item indikator operasi dan pemasok teridentifikasi yang mungkin melanggar atau beresiko tinggi melanggar hak untuk melaksanakan kebebasan berserikat dan perjanjian kerja bersama, dan tindakan yang diambil untuk mendukung hak-hak tersebut (G4-HR4). Aspek pekerja anak dengan item indikator operasi dan pemasok diidentifikasi beresiko tinggi melakukan eksploitasi pekerja anak dan tindakan yang diambil untuk berkontribusi dalam penghapusan pekerja anak yang efektif (G4HR5). Aspek pekerja paksa dan wajib kerja dengan item indikator operasi dan pemasok diidentifikasi beresiko tinggi melakukan pekerja paksa atau wajib kerja dan tindakan untuk berkontribusi dalam penghapusan segala bentuk pekerja paksa dan wajib kerja (G4-HR6) juga tidak diungkapkan dalam laporan tahun 2017 maupun 2018.

Item indikator persentase petugas pengamanan yang dilatih dalam kebijakan atau prosedur hak asasi manusia di organisai yang relevan dengan operasi (G4-HR7) dalam aspek praktik pengamanan, item indikator jumlah total insiden pelanggaran yang melibatkan hak-hak masyarakat adat dan tindakan yang diambil (G4-HR8) dalam aspek hak adat, jumlah total dan persentase operasi yang telah melakukan reviu atau asesmen dampak hak asasi manusia (G4HR9), serta item indiktor persentase penapisan pemasok baru menggunakan kriteria hak asasi manusia (G4-HR10) dan dampak negatif aktual dan potensial yang signifikan terhadap hak asasi manusia dalam rantai pemasok dan tindakan yang diambil (G4-HR11). yang termasuk kedalam aspek asesmen pemasok atas hak asasi manusia. Item indikator jumlah pengaduan tentang dampak terhadap hak asasi manusia yang diajukan, ditangani, dan diselesaikan melalui mekanisme pengaduan formal (G4-HR12) yang termsauk dalam aspek mekanisme pengaduan masalah hak asasi manusia juga tidak diungkapkan dalam Sustainability Report ANTAM didua tahun tersebut.

Dan 10 aspek yang tidak diungkapkan tersebut, juga tidak pernah diungkapkan pada Sustainability Report ANTAM pada tahun-tahun sebelumnya, kemungkinan dikarenakan hal-hal yang disebutkan dalam aspek kinerja lingkungan ini memang tidak pernah dilakukan oleh perusahaan sehingga hal tersebut juga tidak bisa diungkapkan.

\section{Sub-Indikator Masyarakat}

Pada tabel diatas dapat dilihat bahwa ANTAM telah mengungkapkan aspek masyarakat lokal dengan item indikator persentase operasi dengan pelibatan masyarakat lokal, asesmen dampak, dan program pengembangan yang diterapkan (G4-SO1) pada tahun 2017 dan 2018. Untuk item indikator operasi dengan dampak negatif aktual dan potensial yang signifikan terhadap masyarakat lokal (G4-SO2) telah dijelaskan dalam laporan tahun 2017, yaitu permasalahan dibidang pendidikan paling dominan dihadapi masyarakat di sekitar wilayah operasi perusahaan diantarantanya keterbatasan saran fisik berupa ruang belajar, gedung, dan pendukung pembelajaran, kurangnya tenaga pengajar baik kualitas maupun kuantitas serta tingkat kesejahteraan khususnya tenaga pengajar honorer, rendahnya kesadara dan atau keterlibatan masyarakat pada proses penyelenggaraan pendidikan, dan lain-lain.

Namun item indikator ini, tidak diungkapkan lagi pada tahun 2018, kemungkinan hal ini terjadi karena pengungkapan masih sama seperti tahun sebelumnya atau pada tahun bersangkutan sudah tidak ada lagi kerentanan dan risiko terhadap masyarakat lokal dari dampak negatif yang diakibatkan oleh faktor derajat keterasingan ekonomi atau fisik masyarakat lokal, tingkat pengembangan sosial ekonomi, termasuk derajat kesetaraan gender dalam masyarakat, 
dan lain-lain. Untuk aspek anti korupsi, perusahaan hanya menjelaskan tentang item indiaktor komunikasi dan pelatihan mengenai kebijakan dan prosedur anti-korupsi (G4-SO4) dan tidak menjelaskan 2 item indikator lainnya yaitu jumlah total dan persentase operasi yang dinilai terhadap risiko terkait dengan korupsi dan risiko signifikan yang teridentifikasi (G4-SO3) dan insiden korupsi yang terbukti dan tindakan yang diambil (G4-SO5) pada Sustainability Report tahun 2017 maupun 2018, item indikator tersebut juga tidak diuingkapkan pada Sustainabilty Report pada tahun-tahun sebelumnya diduga karena apabila ANTAM melaporkan hal-hal terkait insiden korupsi dalam perusahaan akan memberikan citra negatif terhadap perusahaan sehingga untuk item indikator tidak dilaporkan.

Selanjutnya pada Sustainability Report tahun 2017 dan 2018 perusahaan ANTAM tidak menjelaskan tentang aspek kebijakan publik dengan item indikator nilai total tindakan politik berdasarkan negara dan penerima/ penerima manfaat (G4-SO6), aspek anti persaingan dengan item indikator jumlah total tindakan hukum terkait anti paersaingan, anti-trust, serta praktik monopoli dan hasilnya (G4-SO7) dan aspek kepatuhan dengan item indikator nilai moneter denda yang signifikan dan jumlah total sanksi non-moneter atas ketidakpatuhan terhadap UU dan peraturan (G4-SO8) dalam pengungkapan CSR nya.Untuk aspek asesmen pemasok atas dampak pada masyarakat, pada tahun 2017 dan 2018 hanya item indikator persentase penapisan pemasok baru menggunakan kriteria dampak terhadap masyarakat yang dijelaskan (G4-SO9) sementara item indikator dampak negatif aktual dan potensial yang signifikan terhadap masyarakat dalam rantai pasokan dan tindakan yang diambil (G4-SO10) tidak diungkapkan. Aspek terakhir yaitu mekanisme pengaduan dampak terhadap masyarakat dengan item indikator jumlah pengaduan tentang dampak terhadap masyarakat yang diajukan, ditangani dan diselesaikan melalui mekanisme pengaduan resmi (G4-SO11) tidak diungkapkan pada Sustainability Report ANTAM tahun 2017 maupun 2018.

\section{Sub-Indikator Tanggung Jawab Atas Produk}

Sub-indikator ini terdiri atas 9 item indikator yang terbagi dalam 5 aspek. Pada Sustainability Report tahun 2017 dan 2018 ANTAM hanya mengungkapkan item indikator jenis informasi produk dan jasa yang diharuskan oleh prosedur organisasi terkait dengan informasi dan pelabelan produk dan jasa, serta persentase kategori produk dan jasa yang signifikan harus mengikuti persyaratan informasi sejenis (G4-PR3) serta tidak mengungkapkan item indikator jumlah total insiden ketidakpatuhan terhadap peraturan dan koda sukarela terkait dengan informasi dan pelabelan produk dan jasa, menurut jenis hasil (G4-PR4) dan hasil survei untuk mengukur kepuasan pelanggan (G4-PR5) yang termasuk kedalam bagian aspek pelabelan produk dan jasa.

Sementara untuk aspek lainnya seperti aspek kesehatan dan keselamatan pelanggan, dengan item indikator persentase kategori produ dan jasa yang signifikan yang dampaknya terhadap kesehatan dan keselamatan yang dinilai untuk peningkatan (G4-PR1) dan total jumlah insiden ketidakpatuhan dan koda sukarela terkait dampak kesehatan dan keselamatan dari produk dan jasa sepanjang daur ulang, menurut jenis hasil (G4-PR2), aspek komunikasi pemasaran dengan item indikator aspek privasi pelanggan dan aspek kepatuhan tidak diungkapkan.

Dalam aspek komunikasi pemasaran dengan item indikator jumlah total insiden ketidakpatuhan terhadap peraturan dan koda sukarela tentang komunikasi pemasaran, termasuk iklan, promosi, dan sponsor, menurut jenis hasil (G4-PR7), aspek privasi pelanggan dengan item indikator jumlah total keluhan yang terbukti terkait dengan pelanggaran privasi pelanggan dan hilangnya data pelanggan (G4-PR8) dan aspek kepatuhan dengan item indikator nilai moneter denda yang signifikan atas ketidakpatuhan terhadap UU dan peraturan terkait penyediaa dan 
penggunaan produk dan jasa (G4-PR9) tidak diungkapkan dalam Sustainability Report ANTAM 2017 maupun 2018.

\section{Analisis Tingkat Keluasan dan Kedalaman CSR Tahun 2017 dan 2018}

Berdasarkan perhitungan total skor dalam pengungkapan CSR ANTAM pada tahun 2017 sebesar 137 sedangkan pada tahun 2018 sebesar 110. Dengan pengungkapan terbanyak tahun 2017 dalam bentuk non- moneter, sedangkan indikator komponen terbesar yaitu indikator kinerja lingkungan. Pada tahun 2018 pengungkapan terbanyak juga dalam bentuk non-moneter dengan indikator komponen terbesar juga indikator kinerja lingkungannya. Berikut adalah total perhitungan skoring setiap komponen indikator kinerja perusahaan ANTAM yang diungkapkan dalam pelaporan CSR tahun 2017 dan 2018. Dari total skor tersebut, dikelompokkan kembali berdasarkan kategori pada semua tabel, untuk mengetahui tingkat keluasan dan kedalaman (breadth and depth) Sustainability Report dan berikut pengelompokan kategori dari tingkat keluasan dan kedalaman CSR ANTAM yang dapat dilihat pada tabel dibawah ini.

Tabel 4.

Pengelompokkan Kategori Tingkat Keluasan dan Kedalaman CSR Tahun 2017 dan 2018

\begin{tabular}{|c|c|c|}
\hline Kategori & Skor & Tahun \\
\hline Over the Horizon & $141-194$ & \\
\hline Trailblazers & $121-140$ & 2017 \\
\hline New Benchmarks & $101-120$ & 2018 \\
\hline State-of-the-Art & $81-100$ & \\
\hline Pressing Hard & $61-80$ & \\
\hline Not So Hot & $41-60$ & \\
\hline Ultra Narrow & $21-40$ & \\
\hline Bottom Crawler & $0-20$ & \\
\hline
\end{tabular}

Hasil dari pengelompokkan kategori tingkat keluasan dan kedalaman dari perusahaan ANTAM tahun 2017 adalah Traiblazer merupakan kategori yang menunjukan bahwa perusahaan tersebut telah beroperasi dengan baik dengan nilai 121-140 dan sebagai jalan untuk mendapati kategori paling tinggi yaitu over the horizon. Sedangkan hasil untuk tahun 2018 mengalami penurunan menjadi New Bencmark yang merupakan kategori yang menunjukan perusahaan harus lebih giat lagi mengungkapkan tingkat keluasan dan kedalaman di bidang ekonomi, lingkungan dan sosial agar dapat berkembang lebih baik dan dapat mendorong untuk mendapatkan skor lebih tinggi.

Dari pembahasan dan analisis yang telah dijelaskan penelitian ini menunjukkan bahwa ANTAM sebagai perusahaan BUMN memiliki tingkat pengungkapan lebih tinggi ditahun 2017 dan menurun pada tahun 2018. Hal ini ANTAM dapat dikatakan sebagai perusahaan yang sudah mengungkapkanCSRmeliputi kinerja ekonomi, kinerja lingkungan dan kinerja sosial dengan baik dengan pedoman GRI tebaru yaitu GRI G4, tetapi tetap harus memperhatikan serta meningkatkan pengungkapan CSR setiap tahunnya agar tidak selalu terjadi penurunan. 


\section{Analisis Persamaan Setiap Indikator yang Terdapat Dalam Global Reporting Initiatives G.4 Dengan PROPER}

Global Reporting Initiatives (GRI) G.4 merupakan sebuah pedoman Laporan Keberlanjutan. GRI adalah sebuah kerangka pelaporan untuk membuat Sustainability Report yang terdiri atas prinsip-prinsip pelaporan, panduan pelaporan dan standar pengungkapan (termasuk didalamnya indikator kinerja). Sedangkan PROPER mendorong penataan perusahaan dalam pengelolaan lingkungan, ekonomi dan sosial melalui instrumen insentif dan disinsentif melalui penyebarluasan kinerja perusahaan setiap tahun. Insentif dalam bentuk penyebarluasan reputasi atau citra positif kepada masyarakat dan stakeholders untuk kinerja Hijau dan Emas. Sementara rapor Biru adalah untuk perusahaan yang mampu memenuhi regulasi. Disinsentif dalam bentuk penyebarluasan reputasi atau citra buruk bagi perusahaan yang mempunyai kinerja Merah dan Hitam yang tidak taat regulasi. Dengan begitu dapat kita simpulkan bahwa dalam menilai kinerja lingkungan perusahaan PROPER mampu mendorong perusahaan tidak hanya fokus dalam meraup keuntungan saja, melainkan juga memperhatikan aspek kelestarian lingkungan dan pemberdayaan masyarakat di wilayah operasi perusahaan karena sifatnya yang wajib. PROPER juga dianggap membuat program CSR perusahaan lebih terencana dan tidak lagi berbasis charity semata.

\section{SIMPULAN, KETERBATASAN DAN SARAN Simpulan}

Berdasarkan hasil penelitian ini, maka dapat diambil kesimpulan sebagai berikut berdasarkan analisis data:

a Tingkat pengungkapan indikator kinerja ekonomi, sosial dan lingkungan pada Sustainability Report perusahaanAneka Tambang tbk pada dengan pengungkapkan sebesar 37item indikator pada tahun 2017 (40,66\%) dan 33item Indikator pada tahun 2018 (36,26\%) dari 91 item Indikator GRI G4Guidelines. Tingkat keluasan dan kedalaman (Breadth and Depth) dari Sutainability Report perusahaan Aneka Tambang, Tbk dengan skor 137 yaitu kategori Traiblazers (121-140) tahun 2017 dan skor 116 dengan kategori New Benchmarks (101-120) tahun 2018. Dapat disimpulkan bahwa pengungkapan CSR ANTAM lebih banyak diungkapkan pada tahun 2017 daripada tahun 2018 sejalan pula dengan penurunan peringkat PROPER yang diterima ANTAM pada tahun 2017 yaitu emas, menurun menjadi hijau ditahun 2018.

b. Tingkat persamaan setiap indikator terdapat dalam Global Reporting Initiatives G.4 dengan PROPER berdasarkan analisis terdapat 4 aspek indikator yang memiliki kesamaan yaitu, energi, limbah, air dan keberagaman hayati. Berdasarkan aspek pelaporan yang ada di dalam pedoman GRI G.4 dan aspek pelaporan dinilai yang terdapat dalam PROPER pada dasarnya memiliki kesamaan dalam pengungkapan.

\section{Keterbatasan}

Dalam melakukan penelitian ini, penulis tidak lepas dari berbagai keterbatasan. Peneliti tidak dapat meneliti lebih lanjut mengenai item-item indeks kinerja berdasarkan pedoman GRI dalam beberapa laporan apakah item tersebut sudah diungkapkan atau belum dikarenakan adanya ketidaklengkapan dalam penyusunan tabel indeks seluruh standar pengungkapan dimana respon terhadap pengungkapan tersebut dapat ditemukan dalam laporan. Penelitian ini juga hanya menggunakan data dokumenter tanpa adanya wawancara dan observasi langsung dengan pihak perusahaan. 


\section{Saran}

Berdasarkan dari hasil penelitian ini, dapat disarankan bagi perusahaan- perusahaan di Indonesia dan peneliti selanjutnya yaitu:

a. Diharapkan bagi penelitian selanjutnya, pengambilan sampel perusahaan diperhatikan kembali perusahaan mana yang telah memilikiSustainability Report agar lebih mudah pengelompokkannya ke dalam GRIG4 Guidelines dan memperpanjang periode tahun penelitian.

b. Penelitian ini dapat dijadikan acuan untuk mengunakan objek penelitian dalam sektor lain seperti perbankan dan finansial, industri, infrastruktur danlain-lain.

c. Perusahaan di Indonesia diharapkan mengeluarkan Sustainability Report yang terpisah dari Annual Report agar terdapat transparansi dari pertanggungjawaban seluruh kegiatan perusahaan dari segi ekonomi, sosial dan lingkungan sehingga kepercayaan stakeholder terhadap perusahaan dapat semakinmeningkat.

d. Untuk PROPER diharapkan pihak Kementerian Lingkungan Hidup lebih memberikan penjelasan yang lebih detail terkait aspek-aspek yang dinilai sehingga pihak ketiga, seperti stakeholder, masyarakat, dll. dapat lebih memahami dasar pemberian peringkat.

\section{DAFTAR PUSTAKA}

Akhmaridza, Fuci. 2016. Retrorika pada laporan CSR perusahaan tambang dan kimia yang terdaftar di periode 2011 - 2013. Skripsi. UIN Sunan Kalijaga.

Amalia, 2016. Pengaruh managerial ownership, earnings management, dan dewan komisaris terhadappengungkapan CSR perusahaan. Skripsi. Universitas Negeri Padang.

Aneka Tambang, 2017. Annual Report. di akses 5 september 2018, dari http://www.antam.com

Aneka Tambang, 2018. Annual Report. di akses 5 April 2019, dari http://www.antam.com

Aneka Tambang, 2017. Sustainability Report. di akses 5 September 2018, dari http://www.antam.com

Aneka Tambang, 2018. Sustainability Report. di akses 5 April 2019, dari http://www.antam.com

Ariwendha, Erza dan Dede Abdul Hasyir. Analisis Pengukutan Kinerja CSR Berdasarkan Evaluasi Laporan Berkelanjutan : Studi Kasus Pada PT. ANTAM Tbk.

Chairiri, Anis dan Nugroho, Firman Aji. 2009. Retrorika dalam pelaporan Corporate Social Responsibility; Analisis semiotik atas Sustainability Reporting PT. Aneka Tambang Tbk. Simposium Nasional Akuntansi XXII

Chairiri, Anis dan Erida Gabriella. 2009. Pengaruh Struktur kepemilikan terhadap pengungkapanyanggung jawab sosial perusahaan. Simposium Nasional Akuntansi. Universitas Diponegoro.

Daniri, Mas Achmad, 2008. "Standarisasi Tanggung Jawab Sosial Perusahaan (Bag I)". www.madani-ri.com/2008/01/17/standarisasi-tanggung-jawab-sosialperusahaanbag-i/.

Ghozali, Imam dan Chairiri, Anis. 2007. Teori Akuntansi. Semarang: Universitas Diponegoro.

Erdanu, Yudho. 2010. Pengaruh Jenis Industri Terhadap Luas Tanggungjawab Social (CSR Disclousure) Pada Laporan Tahunan Perusahaan: Studi Empiris Pada Perusahaan Publik Yang Tercatat Di Bursa Efek Indonesia Tahun 2009. Undip. Semarang.

Frondika, Defri. 2012. Analisis Perbandingan Pengungkapan Corporate Social Responsibility (CSR) pada Perusahaan Tambang yang Terdaftar di Bei Tahun 2011 Berdasarkan Global Reporting Initiatives (GRI) G3.1.BINUS. Jakarta 
Global Reporting Initiative.www.globalreporting.org. Diakses pada tanggal 20 Agustus 2018

Global Reporting Initiative (GRIa). 2013. Pedoman Laporan Keberlanjutan G4. Amsterdam . Global Reporting Initiative (GRIb). 2013. GRI Sustainability Reporting Process. Amsterdam

Global Reporting Initiative. GRI Sustainability Reporting Guidelines G3.1. Data indikator pengungkapan Corporate Social Responsibillity (CSR). (www.gobalreporting.org, diakses 20 agustus 2018).

Kementerian Lingkungan Hidup. 2005. Tentang sekilas PROPER dulu, sekarang dan masa mendatang. Jakarta: Deputi bidang pengendalian dampak lingkungan.

Ladina, Pregnandia. Wijono, Topo dan Nuzula, Nila Firdausi. 2016. Analisis Pelaporan Corporate Social Responsibility pada Perusahaan Induk dan Subdiary Tahun 2014 : Studi pada Perusahaan Induk dan Subdiary yang Terdaftar di BEI dan Menggunakan Pedoman GRI G.4. Jurnal Administrasi Bisnis (JAB) , Vol. 41, No. 1, Desember 2016.

Maroza, Witri. 2016. Analisi Pengungkapan Sustaiability Report Pada PT. Aneka Tambang, Tbk dan PT. Vale Indonesia, Tbk Tahun 2013-2014. Skripsi. UNP. Padang.

Nurkhin, Ahmad. 2009. Corporate Governance dan Profitabilitas, Pengaruhnya Terhadap Pengungkapan CSR Sosial Perusahaan. Jurnal Dinamika Akuntansi. Vol.2 No.1.46-55.

Pemerintah Republik Indonesia. PP RI No 47 Tahun 2012 Tentang Tanggungjawab Sosial dan Lingkungan Perseroan terbatas (2012)

Peraturan Menteri Lingkungan Hidup Republik Indonesia Nomor 06 Tahun 2013 Tentang Program Penilaian Peringkat Kinerja Perusahaan dalam Pengelolaan Lingkungan Hidup.

Putra, Eka Nanda. (2011). Pengaruh Karakteristik Perusahaan Terhadap Pengungkapan Corporate Social Responsibility (Csr). Skripsi Universitas Diponegoro.

Rustiarini, 2011. Pengaruh Struktur Kepemilikan Saham pada Pengkukapan Corporate Social Responsibility. AUDI Jurnal Akuntansi dan Bisnis, 6(1), 104-119

Safitri, Nanda Febrina Wahyu. Analisa Pelaporan Pengungkapan Corporate Social Responsibility (CSR) Berdasarkan Pedoman Global Reporting Initiatives (GRI). Skripsi. Universitas Negeri Semarang.

Sakina, Ade. Wahyuni dan Mas'ud. 2014. Narsisme dalam pelaporan coorporate social responsibility: Analisis semiotik atas sustainability reporting PT. Kalti Prima Coal dan PT. Perkebunan Nusantara XIII. Jurnal ekonomi bisnis dan Akuntansi.

Sari, Nuraini. 2014. Analsis Pengungkapan Corporate Social Responsibility Berdasarkan Global Reporting Initiatives (GRI) : Studi Kasus Perusahaan Tambang Batubara Bukit Asam Tbk.

Sugiyono. 2012. Metode Penelitian Kuantitatif Kualitatif dan R\&D. Bandung: Alfabeta

Sugiyono. 2013. Metode Penelitian Kuantitatif Kualitatif dan R\&D. Bandung: Alfabeta

Tarigan, Josua dan Semuel, Hatane. 2014. Pengungkapan Sustainability Report dan Kinerja Keuangan. Jurnal Akuntansi dan Keuangan, Vol. 16, No. 2, 88-101

Undang-Undang Republik Indonesia Nomor 40 Tahun 2007 Tentang Perseroan Terbatas

Wibisono, Y. 2007. Membedah Konsep Dan Aplikasi CSR. Gresik: Fascho Publishing.

Wulolo, Crista Fianica dan Rahmawati, Isna Putri. Analisis Pengungkapan Corporate Social Responsibility Berdasarkan Global Reporting Initiative G4 . Jurnal Organisasi dan Manajemen, Volume 13, Nomor 1, Maret 2017, 53-60.Universitas Sebelas Maret.

Zalti, Suci Eldia.2018. Retrorika Dalam Pengungkapan Informasi Corporate Social Responsibility PT. Semen Padang. Skripsi. Universitas Negeri Padang. 